\title{
KANT O SEBEPOZNÁNÍ ČLOVĚKA
}

\section{Jiří Chotaš}

Kantova nauka o sebepoznání člověka je považována za jednu z nejtemnějších a nejobtížnějších částí jeho filosofie. ${ }^{1}$ Je tomu tak proto, že je založena na teorii vnitřního smyslu, jehož prostřednictvím člověk nazírá sebe sama. Poznává se však pouze tak, jak se sám sobě jeví, a nikoli tak, jak je sám o sobě. Člověk tak je v teoretickém ohledu při poznávání sebe sama podřízen stejným podmínkám, jakým podléhá poznání př́rody.

V kantovském bádání se lze s ohledem na Kantovu nauku o sebepoznání člověka setkat s různými názory. Jedni badatelé popírají, že se Kantovi podařilo problém sebepoznání uspokojivě vyřešit. ${ }^{2}$ Druzí jsou přesvědčeni, že jeho nauku je třeba odmítnout, protože spočívá na předpokladu tzv. „dvojí afekce“, a tedy na mechanistické nauce o poznání, kterou nelze hájit. ${ }^{3}$ A třetí skupina badatelů je toho názoru, že v Kantových spisech, nepublikovaných rukopisech a $\mathrm{v}$ opisech jeho přednášek lze nalézt hned tři různé koncepce empirického sebepoznání. ${ }^{4}$ Další komplikace způsobuje okolnost, že Kant sám tuto nauku v žádném svém spise uceleně nezformuloval. Jeho poznámky na toto téma jsou spíše prríležitostné a neuspokojivé.

Přesto se v následujících řádcích chceme o rekonstrukci Kantovy nauky o sebepoznání člověka pokusit. Omezíme se při tom na druhé vydání Kritiky čistého rozumu, ve kterém je tato nauka rudimentárně načrtnuta. ${ }^{5}$

1 Viz H. E. Allison, Kant's Transcendental Idealism. An Interpretation and Defence, New Haven - London 1983, str. 255.

2 M. C. Washburn, Did Kant Have a Theory of Self-Knowledge?, in: Archiv für Geschichte der Philosophie, 58, 1976, str. 40-56.

3 D. Sturma, Kant über Selbstbewußtsein. Zum Zusammenhang von Erkenntniskritik und Theorie des Selbstbewußtseins, Hildesheim - Zürich - New York 1985, str. 35.

4 H. F. Klemme, Kants Philosophie des Subjekts. Systematische und entwicklungsgeschichtliche Untersuchungen zum Verhältnis von Selbstbewußtsein und Selbsterkenntnis, Hamburg 1996, str. 214-244, zvl. str. 244.

5 Ke Kantovým analýzám sebevědomí a sebepoznání v jeho dalších spisech viz J. Chotaš, Pojem ,vědomi sebe sama“ v Antropologii v pragmatickém ohledu, in: J. Hill - J. Karásek (vyd.), Pojem vědomí: jeho jednota a rozmanitost, Praha 
Navíc má toto vydání tu výhodu, že Kant v něm již předjímá svou praktickou filosofii a důsledky, které z toho pro sebepoznání člověka plynou. Nejprve však vyložme rozdíl mezi pojmovými dvojicemi: ,jev - věc o sobě“ a „phaenomenon - noumenon“. Musíme nejprve objasnit způsoby, jimiž si podle Kanta člověk může být dán jako předmět.

\section{Jev a věc o sobě; phaenomenon a noumenon}

Kant shrnuje sebepoznání člověka do věty: „poznáváme svůj vlastní subjekt jen jako jev, a nikoli tak, jak je sám o sobě. “6 Jak této větě rozumět?

V Kritice čistého rozumu, v části nazvané „Transcendentální estetika“, Kant ukázal, že prostor a čas jsou pouhými formami naší smyslovosti a že nenáležejí věcem samým o sobě. Prostor je „pouhá forma všech jevů vnějších smyslů, tj. subjektivní podmínka smyslovosti a jen za této podmínky se pro nás vnější názor stává možným“". Obdobně i pro čas platí, že je pouze „formou vnitřního smyslu, tj. formou nazírání nás samých a našeho vnitřního stavu“ “. ${ }^{8}$ Jestliže prostor a čas nenáležejí věcem o sobě, pak vše, co se v prostoru a čase jeví, nemůže být věcí samou o sobě (Ding an sich selbst), ale je jen jevem (Erscheinung). ${ }^{9} \mathrm{U}$ obou těchto pojmů se na chvíli zastavme.

2017, str. 63-76. Ve stati se nezmiňujeme o Henrichově kritice Kantovy teorie sebevědomí, protože naším tématem není výklad geneze subjektu myšlení a vědomí jeho identity. Více o této problematice čtenář nalezne v četných Henrichových textech, např. D. Henrich, Fichtes ursprüngliche Einsicht, in: týž - H. Wagner (vyd.), Subjektivität und Metaphysik, Frankfurt a. M. 1966, str. 188-232.

6 I. Kant, Kritika čistého rozumu, přel. J. Loužil, Praha 2001, str. 120 (B 156). V závorce uvádíme též stránkování prvního $(=\mathrm{A})$, příp. druhého $(=\mathrm{B})$ vydání. Překlad bez dalšího upozornění na některých místech upravujeme.

7 Tamt., str. 59 (A 26/B 42).

8 Tamt., str. 64 (A 33/B 49).

9 Toto tvrzení ponecháváme bez důkazu. Vyvrací se jím však námitka Friedricha H. Jacobiho, že Kant v Kritice čistého rozumu nedokázal, proč je nutné přijmout předpoklad „věcí o sobě“. Jacobi v této souvislosti píše: „Musím připustit, že mě tato okolnost při studiu Kantovy filosofie zdržovala ne právě málo, takže jsem musel v jednotlivých letech za sebou začínat studovat Kritiku čistého rozumu vždy znovu, protože jsem byl neustále zmatený z toho, že bez tohoto předpokladu do systému nevstoupím a $s$ oním jsem v něm nemohl zůstat." F. H. Jacobi, Über den transcendentalen Idealismus. Př́loha ke spisu David Hume über den Glauben, oder Idealismus und Realismus (1815), in: týž, Werke, vyd. F. Roth - F. Köppen, II, Darmstadt 1815, str. 304. 
Gerold Prauss svou knihou Kant und das Problem der Dinge an sich způsobil v 70. letech v kantovském bádání senzaci, když poukázal na to, že Kant nechápal spojení „o sobě“ (,an sich“) ve výrazu „věc o sobě“ (Ding an sich) adjektivně, ale adverbiálně. Výraz ,věc o sobě“ je eliptickým vyjádřením slovního spojení „,věc pojednávaná sama o sobě“ (Ding an sich selbst betrachtet). ${ }^{10}$ Spojení „o sobě“ ve výrazu „věc o sobě“ se týká metodického ohledu (respectus), z něhož mohu o jedné a téže věci (Ding, lat. ens) uvažovat. Jeden a tentýž ontický předmět mohu totiž pojímat ve vztahu k smyslům, jak se mi jeví, a tehdy jej nazývám jevem, anebo jej mohu pojímat $\mathrm{v}$ abstrakci od způsobu, jak se mi jeví, a tehdy jej nazývám věc o sobě. Praussův výklad rozdílu mezi „věcí o sobě“ a ,jevem“ byl přijat do sekundární literatury pod názvem „hledisko dvou ohledü“ (two-aspect view). ${ }^{11}$

S ohledem na termín ,jev“ (Erscheinung) rozeznává Kant dva různé druhy jevu: jev ve vnějším smyslu a jev ve smyslu vnitřním. ${ }^{12}$ Jestliže Kant mluví o jevu jednou jako o „představě“ a jindy jako o „předmětu představy“, pak toto vyjádření znamená, že v prvním př́padě je jev totéž co představa, zatímco ve druhém př́ípadě je jev identický s předmětem představy. Jev jako představa je jevem ve vnitřním smyslu - byt' mohl být původně jevem ve vnějším smyslu - a jev jako předmět představy je jevem ve vnějším smyslu.

Proti pojmové dvojici ,jev - věc o sobě“ staví Kant ve svých spisech jinou pojmovou dvojici, totiž ,phaenomenon a noumenon“. V Kritice čistého rozumu, v kapitole „O důvodu rozlišení všech předmětů vůbec na phaenomena a noumena“, čteme:

„Jevy, jsou-li jako předměty myšleny podle jednoty kategorií, se nazývají phaenomena. Přijímám-li však věci, které jsou pouze

10 G. Prauss, Kant und das Problem der Dinge an sich, Bonn 1977², str. 20.

11 G. Zöller, Main Developments in Recent Scholarhip on the Critique of Pure Reason, in: Philosophy and Phenomenological Research, 53, 1993, str. 454. Praussův výklad v sobě skrývá eleganci umožňující vyhnout se při interpretaci Kantovy filosofie noumenalismu a fenomenalismu. Noumenalismus spočívá v tvrzení, že existují dva ontologicky odlišné typy věcí o sobě (tj. Já o sobě a věci o sobě); fenomenalismus oproti tomu hlásá, že všechny jevy jsou pouze představami závislými ve svém bytí na lidské mysli. Pro literaturu k oběma těmto směrům rozširréným v kantovském bádání viz tamt., str. 455 .

12 Např. „Neurčený předmět empirického názoru se nazývá jev.“ I. Kant, Kritika čistého rozumu, str. 54 (A 20/B 34). K uvedenému rozlišení termínu ,jev“ viz M. Baum, The B-Deduction and the Refutation of Idealism, in: The Southern Journal of Philosophy, 25, 1986, str. 90. 
předměty rozvažování, a přesto mohou být jako takové dány názoru, i když ne smyslovému ..., nazývaly by se takové věci noumena (intelligibilia). ${ }^{“ 13}$

Z citované pasáže vyplývá, že fenomén (phaenomenon) je jevem myšleným podle jednoty kategorí́. Kant ovšem tvrdí, že lze uvažovat i předměty, jež jsou „dány“ pouze prostřednictvím rozvažování, a takové předměty pak nazývá noumena či intelligibilia (tj. jako předměty pouze myšlené). Jak však rozumět samotné pojmové dvojici „phaenomenon - noumenon“?

Veškerou oblast předmětnosti rozděluje Kant na předměty nazývající se fenomény a na předměty nazývající se noumena. O rozdílu mezi fenoménem a noumenem pak píše:

„V našem pojmu je nicméně již obsaženo, že když určité předměty jako jevy nazýváme smyslovými jsoucny (phaenomena), odlišujeme způsob, jak je nazíráme, od jejich uzpůsobenosti samé o sobě, takže bud' právě tyto předměty co do této uzpůsobenosti, i když ji v nich přímo nenazíráme, nebo i jiné možné věci, které vůbec nejsou objekty našich smyslů, klademe jakožto předměty myšlené pouze rozvažováním jakoby proti oněm a nazýváme je rozvažovacími jsoucny (noumeny).“14

A rovněž:

„smyslovým jsoucnům sice určitě odpovídají rozvažovací jsoucna, ale mohou existovat i rozvažovací jsoucna, k nimž naše smyslová nazírací mohutnost nemá vưbec žádný vztah.“15

Kant v první pasáži říká, že určité předměty nazýváme jevy, pokud tyto předměty odlišujeme od jejich povahy samé o sobě. Tento způsob pojímání věcí či předmětů jako jevů jsme výše poznali jako „hledisko dvou

13 I. Kant, Kritika čistého rozumu, str. 203 (A 248). Distinkce,,jev - věc o sobě“ se týká způsobu danosti předmětů, zatímco distinkce phaenomenon - noumenon způsobu, jakým jsou předměty myšleny. Je zřejmé, že ,věc o sobě“ je způsob danosti předmětu, o kterém - při abstrakci od lidské smyslovosti - nemůžeme nic vědět. Vysvětlení důvodů, proč Kant zastává tento mysterianismus, ponecháváme na jinou př́ležitost.

14 Tamt., str. 205 (B 306, zvýraznil J. Ch.).

15 Tamt., str. 207 (B 308 n.). 
ohledů“. Jak je z citované pasáže zřejmé, není však tento způsob jediným, jak lze pojmovou dvojici „phaenomenon - noumenon“ chápat. Pojem „noumena“ může také znamenat, že určité možné věci klademe jako předměty myšlené pouze rozvažováním. $Z$ citovaného úryvku vyplývá, že Kant chápe pojmovou dvojici „phaenomenon - noumenon“ nejen jako dvojici vyjadřující „hledisko dvou ohledů“, ale i jako dvojici vyjadřující hledisko dvou ontologicky rozdílných druhů věcí neboli ,hledisko dvou druhů věcí'. ${ }^{16}$

Kantův výklad pojmové dvojice ,phaenomenon - noumenon“ se však komplikuje jeho rozlišováním všech noumen na noumena v negativním smyslu a na noumena ve smyslu pozitivním. Pod pojmem ,noumenon v negativním smyslu“ rozumí Kant: „nějakou věc, která není objektem našeho smyslového názoru, když od svého způsobu nazírání této věci abstrahujeme.“" Jako „noumenon v pozitivním smyslu“ se nazývá „objekt nějakého nesmyslového názoru, když předpokládáme určitý zvláštní způsob nazírání, totiž intelektuální, který nám však není vlastní a jehož možnost ani nejsme s to nahlédnout"“ ${ }^{18}$ Pojem „noumenon v negativním smyslu“ není - jak soudím - problematický a lze si pod ním představit např́iklad předmět vnímaný smysly, abstrahujeme-li od způsobu jeho nazírání. Pojem „noumena v pozitivním smyslu“ je ovšem pro běžnou představu obtížný, protože Kant pod ním rozumí člověka jako určeného zákonem svobody (a nikoli určeného zákony př́rody). Pojem „noumena v pozitivním smyslu“ má důležitý význam pro předpoklad transcendentální svobody vůle a pro možnost mravního zákona. ${ }^{19}$

Kantova teorie sebepoznání tak v sobě skrývá obtíž, že člověk je v ní popisován v různých významech slova předmět. Pokud jde o sebepoznání člověka v teoretickém ohledu, pak je v ní člověk chápán jako jev (tj. jak si je „dán“ ve vnitřním smyslu). Je-li tento jev myšlen podle jednoty kategorií, pak si je člověk fenoménem. ${ }^{20}$ Pokud však abstrahujeme od své smyslové přirozenosti, myslíme se jako noumenon v negativním

16 Baum označuje obě rozdílná chápání distinkce ,jev - věc o sobě“ jako „hledisko dvojího ohledu“ (double-aspect view) a jako „hledisko dvou druhů věcí“ (two-species-of-things-view). Viz M. Baum, The B-Deduction and the Refutation of Idealism, str. $89 \mathrm{n}$.

17 I. Kant, Kritika čistého rozumu, str. 206 (B 307).

18 Tamt.

19 Srv. M. Baum, The B-Deduction and the Refutation of Idealism, str. 89.

20 O různých ohledech, ve kterých lze člověka podle jednoty kategorií tematizovat, pojednává Kant zvláště v kapitole o paralogismech ve druhém vydání Kritiky. Viz I. Kant, Kritika čistého rozumu, str. 257 n. (B 407-409). Z řečeného plyne, 
smyslu. A jak jsme uvedli, v praktickém ohledu se může člověk myslet jako noumenon $\mathrm{v}$ pozitivním smyslu. Vyzbrojeni těmito rozlišeními můžeme nyní přikročit ke Kantově nauce o sebepoznání člověka.

\section{Sebepoznání člověka jako sebeafekce}

Kant popisuje způsob, jímž mohu poznávat předměty (ale i sám sebe), pomocí nauky o afekci. Tato nauka je $\mathrm{v}$ jeho spisech obsažena jen $\mathrm{v}$ rudimentární podobě a již od počátečních dob recepce Kantovy filosofie se stala předmětem četných sporů. Předmět těchto sporů lze shrnout do otázek: Co se jakoby dotýká našich smyslů? Co na nás působí či co nás afikuje? Je to „věc o sobě“, ,jev“, anebo obojí? Kantovští badatelé na tyto otázky odpovídají v zásadě trojím možným způsobem:

1. Nejrozšířenější je názor, že jsme afikováni věcmi o sobě. ${ }^{21}$ Pro tento názor lze nalézt oporu v řadě pasáží z Kantových děl..$^{22}$ Pokud ho ovšem přijmeme, musíme připustit, že Kant si sám odporuje, protože afekce věcmi o sobě popírá princip kauzality a zásadu nepoznatelnosti věcí o sobě.

2. Méně početná skupina badatelů je přesvědčena, že jsme afikováni jevy. ${ }^{23}$ I tento názor lze doložit pasážemi z Kantových děl. ${ }^{24}$ Pokud jej přijmeme, podléhá afekce kauzalitě obdobně jako každý jiný prrírodní proces a nepoznatelnost věcí o sobě tím zůstává nedotčena. Na př́padnou námitku, že Kant přesto $\mathrm{v}$ některých kontextech o afekci věcmi

že výrazy ,jev“ (Erscheinung) a „fenomén“ (phaenomenon) nejsou pro Kanta synonymní.

21 Např. F. H. Jacobi, Über den transcendentalen Idealismus, str. 301 nn.; B. Erdmann, Kants Kritizismus in der ersten und in der zweiten Auflage der Kritik der reinen Vernunft. Eine historische Untersuchung, Leipzig 1878, str. 19; W. Sellars, ,,... this I or he or it (the thing) which thinks ...". Immanuel Kant. Critique of Pure Reason (A 346; B 404), in: týž, Essays in Philosophy and Its History, Dordrecht 1974, str. 75 nn.; P. F. Strawson, The Bounds of Sense. An Essay on Kant's Critique of Pure Reason, London 1966, str. 170-174.

22 Pro seznam těchto pasáží viz E. Adickes, Kant und das Ding an sich, Berlin 1924, str. 28-37.

23 Např. J. G. Fichte, Druhý úvod do vědosloví (1797), přel. J. Karásek, Praha 2008, str. 81 n.; pro bibliografické údaje, z nichž vyplývá, že Cohen a jeho žáci byli stoupenci názoru, že jsme afikováni jevy, viz E. Adickes, Kant und das Ding an sich, str. 44 n.; H. Allison, Kant's Transcendental Idealism, str. 255 nn.

24 Např. „Účinkem předmětu na představivost, pokud jsme jím afikováni, je počitek.“ I. Kant, Kritika čistého rozumu, str. 54 (A 19 n./B 34). 
o sobě výslovně mluví, lze odpovědět, že podobně jako u pojmu „věc o sobě“ jde o eliptické vyjádření. Dobrý důkaz pro tvrzení, že jsme afikováni jevy a nikoli věcmi o sobě, poskytl významný německý badatel Erich Adickes, který ve své kritice Hermanna Cohena poukázal na dvojznačnost kontextů, ve kterých Kant uvádí, že jsme afikováni bud' věcmi o sobě, nebo jevy. ${ }^{25}$

3. Potíže s Kantovou naukou o afekci vedla některé jednotlivé badatele k formulaci paradoxní teorie, že Kant zastává tzv. dvojitou afekci - tj. i prostřednictvím ,jevu“ i prostřednictvím „,věci o sobě“. Autorem této teorie je Hans Vaihinger a jejím hlavním stoupencem byl na sklonku svého života již zmíněný Erich Adickes. ${ }^{26}$ Podle těchto interpretů „věci o sobě“, jež jsou v logicko-teleologických vztazích, afikují mé ,já o sobě“ prostř̌ednictvím afekce mimo čas. ${ }^{27}$ „Já o sobě“ tvoří z těchto vztahů svět jevů, jenž má formu časově-prostorového řádu. Jevy tohoto světa působí jako podněty na smyslové orgány mého empirického já. Empirické já odpovídá na tuto afekci počitky, které jsou prostřednictvím kategorií spojovány do jednoty předmětů vnímání.

Spor mezi kantovskými interprety nelze jednoduše rozhodnout. Domnívám se, že pravdu má ta skupina badatelů, která se domnívá, že nás afikují jevy. Své tvrzení mohu doložit jen nepř́imo, a sice pomocí výkladu Kantovy nauky o sebeafekci.

Kant se zmiňuje o sebeafekci Já v Kritice čistého rozumu pouze ve dvou pasážích, a to $\mathrm{v}$ „Obecných poznámkách k transcendentální estetice“ a v $§ 24$ „Transcendentální dedukce čistých rozvažovacích pojmů“. Obě tyto pasáže jsou doplňkem druhého vydání Kritiky čistého rozumu. První pasáž zní následovně:

„Nejen že představy vnějších smysli̊ v něm [tj. ve vnitřním smyslu] tvoří vlastní látku, jíž zaplňujeme svou mysl, nýbrž čas, do něhož tyto představy klademe a který předchází dokonce i jejich vědomí

25 Viz E. Adickes, Kant und das Ding an sich, str. 44 n.

26 H. Vaihinger, Zu Kants Widerlegung des Idealismus, in: Straßburger Abhandlungen zur Philosophie. Eduard Zeller zu seinem siebzigsten Geburtstage, Freiburg i. Br. - Tübingen 1882, str. 145 nn.; Adickes považuje Kantovu teorii dvojí afekce dokonce za klíč k jeho teorii poznání. Viz název jeho spisu: E. Adickes, Kants Lehre von der doppelten Affektion unseres Ich als Schlüssel zu seiner Erkenntnistheorie, Tübingen 1929. Nověji považuje pouze Sturma za samozřejmé, že Kant byl zastáncem teorie dvojí afekce. Viz D. Sturma, Kant über Selbstbewußtsein, str. 35.

27 Viz E. Adickes, Kants Lehre von der doppelten Affektion unseres Ich als Schlüssel zu seiner Erkenntnistheorie, str. $58 \mathrm{n}$. 
ve zkušenosti a je jakožto formální podmínka základem způsobu, jak je v mysli klademe, obsahuje již vztahy následnosti, současnosti a toho, co je současně s následností (trvalost).“28

Nejprve se zde dočítáme, že představy vnějších smyslů tvoří ve vnitřním smyslu vlastní látku, kterou zaplňujeme mysl. Tato věta by mohla svádět $\mathrm{k}$ domněnce, že vnitřní smysl nemá svou vlastní rozmanitost. ${ }^{29}$ Znamenalo by to, že bychom nebyli schopni např́klad žádných pocitů a afektů. Víme ovšem, že „temné“ představy mohou mít vliv na pocit slasti a žádací mohutnost člověka, aniž bychom jejich prostřednictvím něco poznávali. ${ }^{30}$ Věta o představách vnějších smyslů jako vlastní látce vnitřního smyslu pouze tvrdí, že představy vnějšího smyslu jako nevědomé či temné představy - to vše jsou pro Kanta synonymní pojmy - se stávají představami vnitřního smyslu. Tento proces popisuje Kant v citované pasáži dále jako proces kladení (Besetzen), jehož apriorní podmínku tvoří čas.

V jakém smyslu je však čas apriorní podmínkou procesu kladení? Kant v citované pasáži ř́iká, že čas již obsahuje vztahy následnosti, současnosti a trvalost. Nemůžeme se zde pouštět do podrobností, avšak čas, o němž Kant v citovaném úryvku mluví, je nikoli formou názoru, ale formálním názorem. Rozdíl mezi oběma pojmy vysvětluje Kant v následující pasáži: „Prostor představovaný jako předmět... obsahuje více než pouhou formu názoru, obsahuje totiž shrnutí rozmanitosti, která je dána podle formy smyslovosti, do jedné názorné představy, takže forma názoru dává pouze rozmanitost, zatímco formální názor poskytuje jednotu představy.“31 Čas jako formální názor si představujeme pomocí prostorové analogie jako časovou přímku, při které odhlížíme od prostorového vztahu částí přímky (tj. vztahů „vedle sebe“) a chápeme je jako vyjadřující časové vztahy (tj. vztahy ,po sobě“). Proto může Kant říci, že čas již obsahuje poměr či vztah bytí-po-sobě (tj. sukcesi), vztah současného bytí ( $\mathrm{tj}$. simultaneitu) a vztah toho, co je současně s následností (tj. trvalost). Z modelu času jako přímky vysvítá, že časové určení bez odkazu k prostorovému

28 I. Kant, Kritika čistého rozumu, str. 73 (B 67). K výkladu pasáže srv. H. E. Allison, Kant's Transcendental Idealism, str. 264.

29 Tak soudí např. Allison, viz tamt., str. 259 n.

30 Viz Kantův dopis Marcusi Herzovi z 26. května 1789, in: AA XI, str. 52. Kantovy spisy (vyjma překladů do češtiny) a jeho rukopisnou pozůstalost cituji podle vydání I. Kant, Gesammelte Schriften, vyd. Königlich Preußische Akademie der Wissenschaften, I nn., Berlin 1902 nn. (=AA). Římská číslice udává číslo svazku.

31 I. Kant, Kritika čistého rozumu, str. 122 (B 160 pozn.). 
určení je nemyslitelné. Bez odkazu k pevně dané škále (např. k ciferníku na hodinkách) nemohu totiž jednotlivé časové události datovat. K určení změny (tj. $\mathrm{k}$ přechodu jedné události ze stavu A do stavu non-A) potřebuji něco trvalého, vůči čemu mohu změnu vnímat. Toto trvalé však - jak později uvidíme - nemohu ve vnitřním smyslu nalézt. Čas jako formální názor obsahuje tedy již poukaz na vnější názor. Výše zmiňovaná pasáž nevyjadřuje nic jiného než to, že veškeré vědomí představ ve vnitřním smyslu je podmíněno časem. Kant pak dále pokračuje:

„To však, co může jakožto představa předcházet před každou myšlenkovou činností, je názor, a jestliže ten neobsahuje nic než vztahy, je formou názoru, která - jelikož nepředstavuje nic kromě př́ípadu, kdy je něco kladeno v mysli - nemůže být ničím jiným než způsobem, jak je mysl afikována svou vlastní činností, totiž tímto kladením své představy, a tedy sama sebou, tj. je vnitřním smyslem co do jeho formy. “32

V předchozí citované pasáži o sebeafekci jsme poznali, jakým způsobem čas a priori podmiňuje vnímání veškeré empirické rozmanitosti představ. Nyní se dozvídáme, jak z podmíněnosti veškerého vnímání časem vyplývá, že mysl je při tomto určování pasivní, a nikoli aktivní. Jak tomuto tvrzení rozumět?

Vyjdeme od Kantova mnohoznačného pojmu „mysl“ (Gemüt, lat. animus). V § 24 spisu Antropologie z pragmatického hlediska čteme, že ,mysl si představujeme jako pouhou schopnost pocit'ovat a myslit“..$^{33}$ Pojem mysli tedy v sobě spojuje receptivitu (tj. smyslovost) a spontaneitu (tj. rozvažování). Ř́íká-li Kant, že mysl je afikována svou vlastní činností, a tedy sebou samou, pak toto určení znamená, že spontaneita mysli afikuje její receptivitu. Forma názoru není při této afekci ničím jiným než způsobem, jímž je vnitřní smysl určován co do své formy rozvažo-

32 Tamt., str. 73 n. (B 67 n.) Viz též Kantův rukopisný dodatek: ,V prostoru jsou samé vnější, zatímco ve vnitřním smyslu samé vnitřní vztahy; absolutno chybí.“ Tamt., str. 213, pozn. 208 (Dodatek k A 265).

33 I. Kant, Anthropologie in pragmatischer Hinsicht, AA VII, str. 161. Kant používá v dané pasáži pojem „mysl“ (Gemüth, lat. animus), a to proto, aby se vyhnul metafyzickým implikacím pojmu duše (Seele, lat. anima). V Kantových poznámkách k Sömmeringovu spisu Über das Organ der Seele (AA XII, str. 32; česky: Ze Sömmeringa. O orgánu duše, přel. T. Koblížek, viz níže v tomto čísle časopisu, str. 171-174) z roku 1795 pak čteme: ,Mysli chápeme pouze schopnost (animus) syntetizující dané představy a působící jednotu empirické apercepce, nikoli ještě substanci (anima), co do její, od matérie zcela odlišné, povahy, od níž pak abstrahujeme." 
váním, totiž kladením představy časových vztahů do smyslovosti. Jak tato sebeafekce - tj. afekce vnitřního smyslu rozvažováním - probíhá, uvidíme vzápětí. Proč je však mysl při tomto určování pasivní? Lidské, diskursivní rozvažování si žádnou rozmanitost není schopno dát, a musí ji proto hledat ve smyslech. ${ }^{34} \mathrm{Z}$ toho vyplývá, že pokud forma smyslu podmiňuje veškeré vnímání rozmanitosti, nemohu si být empirické rozmanitosti představ vědom nijak jinak než pod podmínkou času, a tedy prostřednictvím smyslovosti, protože čas je formou vnitřního smyslu. Vnitřní zkušenost - jako sjednocení jednotlivých empirických obsahů vědomí - je možná pouze pod podmínkou, že v představě času uvádím představy vnějšího smyslu do jednoty vědomí - tj. stávám se jich vědom jako svých představ.

V § 24 Kritiky čistého rozumu nazvaném „O aplikaci kategorií na předměty smyslů vůbec“ Kant mj. pojednává o otázce, jak si lze proces kladení časových vztahů do smyslovosti představit blíže. Uvádí zde:

„Nemůžeme si myslit žádnou př́mku, aniž bychom ji v myšlenkách vedli, žádnou kružnici, aniž bychom ji opsali, nedokázali bychom si vůbec představit tři rozměry prostoru, aniž bychom z téhož bodu spustili tři kolmice, a dokonce bychom si nedokázali představit ani čas, kdybychom při vedení přímky (která má být vnější obraznou představou času) nesledovali pouze činnost syntézy rozmanitosti, jejíž pomocí sukcesivně určujeme vnitřní smysl, a tím sledujeme sukcesi tohoto určení. “35

Představa přímky, kružnice, a dokonce i představa prostoru a času je v citované pasáži spojena s činností syntézy rozmanitosti, pomocí níž sukcesivně určujeme vnitřní smysl. Jak tomuto tvrzení rozumět? Z postulátů eukleidovské geometrie vyplývá, že mohu určité pojmy (napřr. pojem př́mky, kružnice, koule) konstruovat $\mathrm{v}$ názoru a priori prostřednictvím obrazotvornosti (Einbildungskraft, lat. imaginatio). Pojem vystupuje $\mathrm{v}$ této konstrukci v roli pravidla (Regel), jež udává, jak má být rozmanitost čistého názoru sjednocena. Aktem konstrukce či sestrojením

34 „Rozvažovací schopnost, v níž by byla prostřednictvím sebevědomí zároveň dána veškerá rozmanitost, by nazírala; naše [rozvažovací schopnost] může jen myslit a názor musí hledat ve smyslech“ (B 135; upravený překlad). K rozdílu mezi lidskou, diskursivní rozvažovací schopností a hypotetickou božskou nazírající rozvažovací schopností viz I. Kant, Kritika soudnosti, přel. V. Špalek - W. Hansel, Praha $2015^{2}$, str. 229 n. (§ 76).

35 I. Kant, Kritika čistého rozumu, str. 119 (B 154). 
pojmu se dotyčnému pojmu dostává bytí (Dasein). Vezmeme-li si např́iklad pojem kružnice, pak tento pojem říká, že kružnice je rovinná čára, jejíž všechny body mají od středu stejnou vzdálenost. Mám-li kružnici sestrojit, musím pomocí kružítka opsat rovinnou čáru splňující danou podmínku. Bez důkazu ponechávám tvrzení, že mechanický nákres kružnice v empirickém názoru předpokládá jako svůj vzor (Muster) konstrukci pojmu kružnice v názoru čistém. ${ }^{36}$ Obdobně jako konstruuji přímku a kružnici, mohu podle Kanta konstruovat i pojem prostoru a času.

Soustřed'me se pouze na konstrukci pojmu času. Kant v pasáži citované výše říká, že bychom si čas nemohli představit, „kdybychom při vedení prímky ... nesledovali pouze činnost syntézy rozmanitosti, jejíž pomocí sukcesivně určujeme vnitřní smysl, a tím sledujeme sukcesi tohoto určení “. ${ }^{37}$ Určení času jako pojmu se stane srozumitelnější, pokud přihlédneme k následujícímu vysvětlení:

„Pohybem jako činností subjektu (nikoliv jako určením nějakého objektu), a tedy syntézou rozmanitosti v prostoru, když od rozmanitosti v prostoru abstrahujeme a sledujeme pouze činnost, kterou určujeme vnitřni smysl podle jeho formy, je tak dokonce pojem sukcese teprve vytvářen. Rozvažování tedy ve vnitřním smyslu nenalézá již nějaké hotové spojení rozmanitosti, nýbrž vytvář́ je tím, že vnitřní smysl afikuje. “"38

Rozvažovací schopnost nenalézá ve vnitřním smyslu spojení rozmanitosti, protože forma vnitřního názoru, jíž je čas, obsahuje sice čistou rozmanitost, avšak tato rozmanitost postrádá jednotu. Rozvažování samo vytváŕí spojení rozmanitosti ve vnitřním smyslu, a to tím, že vnitřní smysl afikuje co do jeho formy. Afekce vnitřního smyslu co do jeho formy znamená, že rozvažování klade do smyslovosti představu časových

36 K bližšímu výkladu vztahu mezi čistým a empirickým názorem jakož i ke Kantovu pojmu konstrukce viz jeho recenzi časopisu Philosophisches Magazin (vyd. J. A. Eberhard), nazvanou Über Kästners Abhandlungen (O Kästnerových pojednáních), in: AA XIII, str. 410-423, a Kantovu poznámku ke spisu Über eine Entdeckung nach der alle neue Kritik der reinen Vernunft durch eine ältere entbehrlich gemacht werden soll (O objevu, jímž má být všechna nová kritika čistého rozumu pomocí jedné starší učiněna postradatelnou), in: $A A$ VIII, str. $191 \mathrm{n}$.

37 I. Kant, Kritika čistého rozumu, str. 119 (B 154).

38 Tamt., str. 119 n. (B 154 n.) 
vztahů. Bez důkazů ponechávám tvrzení, že z těchto vztahů je nejdůleŽitější vztah následnosti neboli sukcese. ${ }^{39}$

Jak však vztah časové následnosti ve vnitřním smyslu vzniká? Co znamená Kantovo záhadné tvrzení, že pojem sukcese vzniká ve vnitřním smyslu pohybem subjektu, a nikoli určováním objektu? Jeho úvaha ve výše citované pasáži vychází z představy času jako časové př́ímky. Víme, že o věcech poznáváme a priori jen to, co do nich sami vkládáme. ${ }^{40}$ Čas proto nelze na objektech v prostoru takříkajíc odečíst, ale představa času má svůj původ v subjektu, resp. přesněji řečeno v jeho činnosti (Handlung). O této činnosti Kant v citované pasáži říká, že je „syntézou rozmanitosti v prostoru, když od rozmanitosti v prostoru abstrahujeme a sledujeme pouze činnost, kterou určujeme vnitřni smysl podle jeho formy“ “. ${ }^{41}$ Syntéza rozmanitosti v prostoru znamená, že si určitou rozmanitost představujeme jako sjednocenou do prostorové přímky, jejíž všechny části jsou vedle sebe. Pokud abstrahujeme od prostoru - tj. od jejich prostorového určení neboli vztahů „vedle sebe“-, vytváríme pohybem bodu po prímce jednotlivé časové úseky, které jsou ve vztahu po sobě. Časová - a právě tak ani prostorová - přímka se neskládá z jednotlivých bodů jako svých částí, ale vzniká teprve zastavením pohybu bodu na př́imce. ${ }^{42}$ Toto zastavení znamená, že jsem si v určitém časovém okamžiku $\mathrm{t}_{1}$ vědom představy $\mathrm{A}$. Opětovným pohybem po př́mce vědomí představy A ztrácím a stávám se $\mathrm{v}$ okamžiku $\mathrm{t}_{2}$ vědom představy B. Pojem sukcese neznamená nic jiného než vědomí, že představa B $\mathrm{v}$ okamžiku $\mathrm{t}_{2}$ je odlišná od představy A $\mathrm{z}$ okamžiku $\mathrm{t}_{1}(\mathrm{t} \mathrm{j}$. je představou non-A). $\mathrm{K}$ tomu, abych si mohl být dvou představ $\mathrm{A}$ a $\mathrm{B}$ vědom jako následujících po sobě, musím vnímat změnu, kterou představa A podstupuje: její přechod z bytí do nebytí. Pouze tak mohu říci, že po představě A následuje představa $\mathrm{B}$ neboli non-A. V poznámce $\mathrm{k}$ výše citované pasáži Kant povahu syntézy umožňující pojem sukcese vysvětluje: „Pohyb jako opisování určité dráhy v prostoru je čistý actus sukcesivní syn-

39 Odpověd' na otázku, jak spolu souvisejí jednotlivé mody času - tj. sukcese a simultaneita -, nalezne čtenář v Kritice čistého rozumu, v oddíle nazvaném „Analogie zkušenosti“; viz I. Kant, Kritika čistého rozumu, str. 153-178 (A 176-218/B 218-264). K výkladu tzv. první a druhé analogie viz H. E. Allison, Kant's Transcendental Idealism, str. 199-234.

40 I. Kant, Kritika čistého rozumu, str. 20 (B XVIII).

41 Tamt., str. 120 (B 155).

42 Ke Kantovu tvrzení, že prostor a čas se neskládají z bodů a okamžiků jako svých jednoduchých částí, ale že tyto části teprve vznikají omezením původní celkové představy prostoru a času, viz tamt., str. 288 (A 440/B 468). 
tézy rozmanitosti ve vnějším názoru vůbec prostřednictvím produktivní obrazotvornosti a patří nejen do geometrie, nýbrž dokonce i do transcendentální filosofie. “433 Syntézou, která je zodpovědná za sjednocování rozmanitosti představ i bez jejich př́tomnosti ve smyslech, je syntéza produktivní obrazotvornosti. ${ }^{44}$

Z čeho však vyplývá, že člověk se může poznat jen jako jev, a nikoli jak je sám o sobě? Odpověd' na tuto otázku obsahují obě výše citované pasáže o sebeafekci. Z první pasáže vyplývá, že veškeré lidské vnímání je podmíněno časem. ${ }^{45}$ Jestliže je však veškeré naše vnímání takto podmíněno, pak je veškeré naše vnímání smyslové, protože jak Kant v „Transcendentální estetice“ ukázal, nemáme jiné formy než čas a prostor, jejichž prostřednictvím bychom mohli věci nazírat. ${ }^{46} \mathrm{Z}$ druhé pasáže plyne, že čas můžeme vnímat pouze prostřednictvím časové přímky. ${ }^{47}$ Toto tvrzení znamená, že časové vztahy si můžeme představit pouze $\mathrm{v}$ analogii s prostorovými vztahy (viz prostorový model časové přímky popsaný výše). Protože však bylo o prostoru v „Transcendentální estetice“ ukázáno, že je pouhou subjektivní formou naší smyslovosti, můžeme jeho pomocí nazírat věci ne tak, jak jsou samy o sobě, ale jen tak, jak se nám jeví. Vzhledem $\mathrm{k}$ tomu, že představa času je možná pouze prostřednictvím představy prostoru - jak jsme právě vysvětlili -, můžeme i my sami sebe nazírat ne tak, jak sami o sobě jsme, ale jen tak, jak se sobě jevíme. ${ }^{48}$

43 Tamt., str. 120 (B 155 pozn.).

44 „Pokud je obrazotvornost spontaneitou, nazývám ji občas také produktivní obrazotvorností, a odlišuji ji tak od obrazotvornosti reproduktivní, jejíž syntéza je podřízena pouze empirickým zákonům, totiž zákonům asociace, a která proto nepřispívá ničím k vysvětlení možnosti poznání a priori, a proto nepatří do transcendentální filosofie, nýbrž do psychologie.“ Tamt., str. 118 (B 152). Výklad Kantova pojetí obrazotvornosti nalezne čtenář např. v knize H. Mörchen, Die Einbildungskraft bei Kant, Tübingen 1970 (19301), str. 14.

45 I. Kant, Kritika čistého rozumu, str. 73 n. (B 67 n.)

46 Tamt., str. 59-62, 64-66 (A 26-30/B 42-45; A 32-36/B 49-53).

47 Tamt., str. 119 (B 154).

48 Pokud mohu soudit, není Kantova nauka o sebepoznání člověka zatížena psychologismem. Kant sám poukazuje na rozdíl mezi svou naukou o sebepoznání a tím, jak se člověk poznává prostřednictvím introspekce (viz tamt., str. 120; B 156 n.). Tento druhý typ poznání mu slouží jen jako ilustrace jeho pojetí, nikoli jako důkazní prostředek. Rozdíl mezi oběma způsoby poznání lze snad vyjádřit tak, že Kant ve své nauce o sebepoznání člověka formuluje epistemické podmínky, za nichž je lidské poznání (a sebepoznání) možné, než že by se dovolával dobových představ o lidských schopnostech. 


\section{Vnitřní a vnější zkušenost}

V předchozím výkladu jsme shrnuli Kantovu teorii sebepoznání člověka do věty, že poznáváme svůj vlastní subjekt jen jako jev, a nikoli tak, jak je sám o sobě. Jako hlavní argument jsme uvedli tvrzení, že veškeré naše vnímání je podmíněno časem, a tedy smyslovostí. Kantův argument je ovšem platný pouze za předpokladu, že čas sám není vlastností věcí o sobě. Pokud by byl totiž čas vlastností věcí o sobě, poznávali bychom sice všechny ostatní věci prostřednictvím vnějšího názoru jen jako jevy, avšak nás samé bychom prostřednictvím vnitřního názoru mohli poznat jako věc o sobě. Je tedy třeba ukázat, jaký je vztah mezi vnitřním a vnějším názorem, anebo jinak řečeno, jak spolu souvisí vnitřní a vnější zkušenost.

Důkazu vztahu mezi vnitřním a vnějším smyslem se Kant věnuje v druhém vydání Kritiky čistého rozumu v oddílu nazvaném „Vyvrácení (materiálního) idealismu““. ${ }^{49} \mathrm{Na}$ poslední chvíli před vydáním spisu $\mathrm{v}$ roce 1787 byla $\mathrm{k}$ tomuto důkazu $\mathrm{v}$ předmluvě připojena obšírná poznámka obsahující textovou emendaci. ${ }^{50}$ Jak si Kant vztah mezi vnitřním a vnějším smyslem představuje? ${ }^{51}$

Před vlastním důkazem, jímž se materiální idealismus popírá, Kant nejprve rozlišuje dva druhy materiálního idealismu. Prvním z nich je tzv. dogmatický idealismus spočívající v tvrzení, že existence předmětů v prostoru mimo nás není možná. Jako zastánce tohoto idealismu je uveden George Berkeley, jenž ,prohlašuje prostor se všemi věcmi, k nimž patř́ jako jejich neoddělitelná podmínka, za něco, co je samo o sobě nemožné, a proto má i všechny věci v prostoru za pouhé fikce“. ${ }^{52}$ Berkeley podle Kanta předpokládá, že prostor je věcí o sobě, z čehož vyplývá, že

49 Tamt., str. 183-185 (B 274-279).

50 Tamt., str. 29 n. (B XXXIX-XLI).

51 Ve vydání Kritiky čistého rozumu z roku 1781 je vyvrácení materiálního idealismu věnován tzv. čtvrtý paralogismus v oddílu nazvaném „Transcendentální dialektika“ (viz tamt., str. 546-554 [A 366-380]). Tuto kapitolu spolu s částmi kapitoly „Dedukce čistých rozvažovacích pojmů“ (viz tamt., str. 519-536 [A 95-130]) Kant pro druhé vydání spisu v roce 1787 kompletně přepracoval. Oddíl nazvaný „Vyvrácení materiálního idealismu“ se tak přesunul do části nazvané „Postuláty empirického myšlení vůbec“" (viz tamt., str. 178 nn. [A 218 nn./B 265 nn.]). Pro důvody, jež Kanta k tomuto přepracování vedly, viz L. Gäbe, Die Paralogismen der reinen Vernunft in der ersten und in der zweiten Auflage von Kants Kritik, disertace Marburg 1954, str. 108-133.

52 I. Kant, Kritika čistého rozumu, str. 183 (B 274). 
všechny věci, pro které tvoří podmínku jejich existence, jsou pouhými fikcemi. Přijmeme-li totiž předpoklad prostoru jako věci o sobě, nelze nahlédnout dvojí: 1. Jak mohou předměty smyslů existovat nezávisle na našich smyslech (tj. jako věci o sobě)? A dále: 2 . Jak lze o předmětech našich smyslů tvrdit něco více než jen to, že jsou to předměty našich smyslů? Skutečnost, že se představy vnějších smyslů nacházejí v nás, ještě nic neříká o tom, zda jim neodpovídá něco, co je mimo nás (např̀. věc o sobě). Přestože zde nemůžeme zabíhat do podrobností, uved'me, že tzv. první argument o prostoru v části nazvané „Transcendentální estetika“ obsahuje právě důkaz, jak určité představy - či přesněji řečeno počitky - se na něco mimo nás vztahovat mohou. ${ }^{53}$ Dogmatický idealismus tedy na otázku, jak spolu souvisí vnitřní a vnější zkušenost, neposkytuje odpověd', protože pojem vnější zkušenosti vůbec nezná.

Druhým druhem materiálního idealismu je tzv. problematický idealismus spočívající v tvrzení, že existence předmětů v prostoru mimo nás je nedokazatelná. Stoupencem tohoto typu idealismu je údajně Descartes, jenž ,prohlašuje za nepochybné jen jediné empirické tvrzení..., totiž: Já jsem“. ${ }^{54}$ Problematický idealista nic netvrdí o tom, zda prostor je věcí o sobě či nikoli, a pouze zastává názor, že existenci předmětů mimo nás nelze dokázat bezprostřední zkušeností. Podle této nauky jsme vždy vystaveni pochybnosti, zda našim představám vnějších věcí vskutku také nějaké vnější věci odpovídají. Například sen spočívá právě v představách vnějších věcí, jež mají původ v nás samých. Jestliže chceme problematický idealismus vyvrátit, musíme prokázat, že „o vnějších věcech máme i zkušenost, a nikoli jen fantazijní představu“, neboli musíme dokázat, že „,i naše vnitřní, pro Descarta nepochybná zkušenost je možná jen za předpokladu vnější zkušenosti“ “. ${ }^{55}$ Vlastní Kantův důkaz sestává z poučky, z důkazu a ze tří poznámek, které mají vysvětlující charakter. Soustřed'me se nejprve na poučku. Říká se v ní:

„Pouhé, avšak empiricky určené vědomí mé vlastní existence dokazuje existenci předmětů v prostoru mimo mne. “56

53 Tamt., str. 56 (A 23/B 38). K rozboru tohoto důkazu viz J. Ebbinghaus, Kants Lehre von der Anschauung a priori, in: G. Prauss (vyd.), Kant, Frankfurt a. M. 1973, zvl. str. 57-60.

54 I. Kant, Kritika čistého rozumu, str. 183 (B 274).

55 Tamt. (B 275).

56 Tamt. 
Poučka obsahuje tezi, o níž není zřejmé, co znamená. Přesto je z ní ale na první pohled patrné, jakým způsobem bude Kant při vyvrácení problematického idealismu postupovat. Jestliže nauku o problematickém idealismu lze shrnout do tvrzení: „Jedině jistá je vnitřní zkušenost, vnější zkušenost je nejistá“, pak Kant tvrdí: „Dokonce již sama vnitřní zkušenost dokazuje, že vnější zkušenost je jistá." Přijímá tedy předpoklad problematického idealisty (tj. větu: „vnitřní zkušenost je jistá"), a jeho důkaz ${ }^{57}$ sestává z kroků, jejichž cílem je odůvodnit tvrzení, že sám výchozí předpoklad má vnější zkušenost za svou podmínku. Kantův důkaz sestává z polysylogismu. První sylogismus zní následovně:

„Jsem si vědom své existence jako určené v čase. Každé časové určení předpokládá něco trvalého ve vnímání. Toto trvalé ale nemůže být něčím ve mně, protože má existence $\mathrm{v}$ čase může být určena teprve tímto trvalým. Vnímání tohoto trvalého je tedy možné jen prostřednictvím nějaké věci mimo mne, a nikoli prostřednictvím pouhé představy nějaké věci mimo mne. ${ }^{\text {"58 }}$

V citované pasáži Kant nejprve ř́íká, že ,jsem si vědom své existence jako určené v čase“. Jak této větě rozumět? Na jednu stranu má představa času svůj základ ve mně, a na stranu druhou jsem si údajně vědom svého Já v čase. Není mezi těmito tvrzeními zjevný rozpor? Kant je přesvědčen, že nikoli. Povaha představy času nás totiž nutí, abychom se myslili ve dvojím významu: jako subjekt myšlení (v němž má představa času svůj základ) a jako objekt vnímání ve vnitřním smyslu (jako empiricky určené vědomí v čase). Čas je ve mně a já jsem v čase. Čím je tato obojetnost představy času dána? V Reflexi č. 5655 z let 1788-1789 čteme:

„To - že jsem v čase, jenž je přesto pouhý vztah ve mně, následně že continens je contentum a já jsem v sobě samém - již naznačuje, že se myslím ve dvojím významu. ${ }^{\text {" } 59}$

57 Kant tvrdí, že jeho důkaz je jediným možným důkazem reality vnějšího jevu. Tento důkaz je transcendentálním důkazem (srv. tamt., str. 470 [A 787/B 815]). Ke Kantově teorii důkazu a k její interpretaci u Strawsona (jako tzv. „,transcendental argument") viz M. Baum, Deduktion und Beweis in Kants Transzendentalphilosophie, Königstein (Ts.), str. 173-210.

58 I. Kant, Kritika čistého rozumu, str. 184 (B 275).

59 I. Kant, $A A$ XVIII, str. 314. 
Čas jako „pouhý vztah ve mně“ jsme v předchozí kapitole naší studie poznali jako vztah sukcese představ, jehož prostřednictvím se jich stávám vědom. V tomto ohledu má představa času svůj základ ve mně, protože já jsem tím, kdo představu vztahů do smyslovosti klade. Na druhou stranu ,jsem v čase“, protože jsem si vědom stavů své mysli jako procesu sjednocování jednotlivých představ, jichž se stávám vědom. Formu sjednocování přitom tvoř́ čas jako forma názoru. Jestliže Kant říká, že jsem si vědom své existence jako určené v čase, pak toto tvrzení neznamená nic jiného, než že jsem si vědom stavů své mysli jako sjednocených do syntetické jednoty (vnitřní) zkušenosti. Kant neříká, že $\mathrm{k}$ důkazu existence předmětů mimo mne dostačuje pouhé vědomí mé vlastní existence, avšak že toto vědomí musí být empiricky určeno. Pouhé vědomí mé vlastní existence je neurčeným empirickým názorem neboli vjemem. ${ }^{60}$ Tento vjem znamená, že jsem si vědom pouze jedné určité představy. Např́iklad nyní jsem si vědom kmene stromu a poté jeho listů. K empiricky určenému vědomí mé existence v čase je však třeba, abych jednotlivé vjemy pojímal v syntetické jednotě. (Např. „Nejprve vnímám kmen stromu, a poté vnímám jeho listy.") Jen tak může vzniknout (vnitřní) zkušenost.

Vlastní důkaz existence předmětů mimo mne se opírá o tvrzení, že „každé časové určení předpokládá něco trvalého ve vnímání“. ${ }^{61}$ Toto trvalé je něčím, co mi umožňuje vnímat veškerou změnu (Veränderung) a vůči čemu mohu určovat veškerou střídu (Wechsel) představ. Kant v této souvislosti formuluje dvě tvrzení: jedno slabší a jedno silnější. Slabší tvrzení říká, že „toto trvalé ... nemůže být něčím ve mně, protože má existence $\mathrm{v}$ čase může být určena teprve tímto trvalým“". ${ }^{62}$ Silnější tvrzení pak obsahuje textová emendace z předmluvy k druhému vydání spisu: „Toto trvalé však nemůže být názorem ve mně. Všechny určující důvody mé existence, které lze ve mně nalézt, jsou totiž představami a jako takové vyžadují samy něco trvalého, co je od nich odlišné a ve vztahu k čemu by mohlo být určeno jejich střídání; toto trvalé vyžaduje tedy i má existence v čase, v němž se střídají، “63 Rozdíl mezi oběma tvrzeními je na první pohled zřejmý: slabší tvrzení pouze vylučuje možnost, že hledané trvalé je něčím ve mně, zatímco silnější tvrzení obsahuje požadavek, že hledané nemůže být ve mně názorem, a to názorem

\footnotetext{
60 Viz I. Kant, Kritika čistého rozumu, str. 265 (B 422 pozn.).

61 Tamt., str. 184 (B 275).

62 Tamt.

63 Tamt., str. 29 (B XXXIX).
} 
vnitřním. Kantovo tvrzení se stane srozumitelnější, pokud přihlédneme k Reflexi č. $6311 \mathrm{z}$ roku 1790:

„Čas sám sice trvá, ale nemůže být sám vnímán, tudíž musí existovat něco od něj odlišného, na čem můžeme pozorovat stř́idu v čase. Toto trvalé nemůžeme být my sami, jelikož jsme právě jako předmět vnitřního smyslu určeni časem; trvalé proto může být kladeno pouze do toho, co je dáno skrze vnější smysl. Možnost vnitřní zkušenosti tedy předpokládá realitu vnějšího smyslu.“64

Realita vnějšího smyslu je tím, co činí vnitřní zkušenost možnou. Toto zjištění lze vyjádřit také tak, že věc (Ding) mimo mne - tj. ve vnějším smyslu - činí možným vnímání toho, co je trvalé. Právě tolik však tvrdí závěrečná věta Kantova prvního sylogismu citovaného výše.

Druhý sylogismus Kantova důkazu, jímž má být vyvrácen materiální idealismus, zní:

„Určení mé existence v čase je tedy možné jen prostřednictvím existence skutečných věcí, které vnímám mimo sebe. Vědomí v čase je však nutně spojeno s vědomím možnosti tohoto časového určení: Je tedy nutně spojeno i s existencí věcí mimo mne jako s podmínkou časového určení, tj. vědomí mé vlastní existence je zároveň bezprostředním vědomím existence jiných věcí mimo mne." ${ }^{\text {"65 }}$

Podle Kanta je „vjem ... jediným znakem skutečnosti“ ${ }^{66} \mathrm{O}$ nějaké věci, at' již jsem to já sám nebo nějaká věc odlišná ode mne, mohu říci, že je skutečná, pouze když ji vnímám. Ř́ká-li tedy Kant v citované pasáži, že „určení mé existence v čase je... možné jen prostřednictvím existence skutečných věcí", pak toto tvrzení znamená, že bez vztahu k počitkům tvořícím matérii názoru si dokonce nemohu být vědom ani sebe jako bytosti určené v čase. To, že skutečné věci vnímám, mi umožňuje, abych odlišil skutečnost (Wirklichkeit) od snů a stavů šílenství. V obou posledně jmenovaných stavech mám totiž prostřednictvím obrazotvornosti fantazijní představu (Einbildung), nikoli však počitek (Empfindung). V Reflexi č. 6313 z roku 1790 o vztahu mezi možností časového určení, tím, co trvá, a předměty vnějšího smyslu čteme:

64 I. Kant, $A A$ XVIII, str. 611.

65 I. Kant, Kritika čistého rozumu, str. 184 (B 275 n.).

66 Tamt., str. 182 (A 225/B 273). 
„Současné bytí A a B si nelze bez toho, co je trvalé, vůbec představit. Nebot' všechna aprehenze je vlastně sukcesivní. Pokud se ale sukcese nemá dít pouze kupředu od A k B, nýbrž také (jak často si přeji) dozadu, od B k A, je nutné, aby A trvalo. Představy smyslů, A a B, musejí tedy mít nějaký jiný důvod než ten, který je ve vnitřním smyslu, ale přesto v nějakém smyslu, čili ve vnějším smyslu; tudíž předměty vnějších smyslů musejí existovat." ${ }^{\text {67 }}$

Existence předmětů vnějších smyslů je nutná, pokud má být vnitřní zkušenost možná. Z pohybu bodu na časové přímce vyplývá, že sukcese je pohybem vnímání kupředu (aufwärts) od představy A, jíž jsem si byl vědom, $\mathrm{k}$ představě $\mathrm{B}$, jíž se teprve stávám vědom. Kdyby představa A přestala trvat, nemohl bych si jí být při vnímání dozadu (rückwärts), tj. od B k A, vědom jako identické představy s představou vnímanou před chvílí. Prostřednictvím obrazotvornosti - jako schopnosti představovat si předmět $\mathrm{i}$ bez jeho prítomnosti ve smyslech - sice mohu v paměti vědomí představy A podržet, avšak nemohu zaručit, že vnímaná představa A bude identická s představou A vnímanou před chvílí. Mohla by být pouze identická $\mathrm{s}$ tou představou, kterou mám o představě A v paměti. Bez trvalosti tedy nelze myslit žádné současné bytí představ. ${ }^{6}{ }^{8}$

\section{Sebepoznání v praktickém ohledu}

Poté co jsme se seznámili s Kantovou teorií sebepoznání v teoretickém ohledu, obrat'me se ještě alespoň stručně ke Kantově teorii sebepoznání člověka v ohledu praktickém. Kant o tomto druhu sebepoznání v Kritice čistého rozumu píše:

67 I. Kant, $A A$ XVIII, str. 614.

68 Kantovo bližší určení toho, co trvá, ponechávám stranou. Kant rozlišuje trvání (Dauer) od trvalosti (Beharrlichkeit). Trvání je omezeno pouze na ohraničenou dobu, zatímco trvalost znamená „existenci ve veškerém čase“ (I. Kant, Kritika čistého rozumu, str. 160 [A 185/B 228]). Trvalost není empirickým pojmem, ale schématem kategorie substance, tj. apriorním časovým určením (viz tamt., str. 134 [A 144/B 183]). V rozmanitosti empirického názoru jí odpovídá hmota (Materie). Materialitu hmoty vytváří její neprostupnost (Undurchdringlichkeit). K bližšímu vymezení trvalosti viz M. Baum, Deduktion und Beweis in Kants Transzendentalphilosophie, str. 98. 
„Jedině člověk, který jinak poznává celou př́rodu pouze prostřednictvím smyslů, poznává sebe sama i prostřednictvím pouhé apercepce, a sice $\mathrm{v}$ jednáních a vnitřních určeních, která nemůže vůbec počítat k smyslovým dojmům, a je ovšem sám sobě jednak fenoménem, jednak ale - totiž s ohledem na jisté mohutnosti - pouze inteligibilním předmětem, poněvadž jeho jednání nelze vůbec počítat $\mathrm{k}$ receptivitě smyslovosti. Tyto mohutnosti nazýváme rozvažováním a rozumem. “69

Citovaná pasáž se zdá svědčit ve prospěch teze, že noumenální poznání Já je možné, protože jak jinak máme rozumět Kantově větě, že člověk „poznává sebe sama i prostřednictvím pouhé apercepce“, a to nezávisle na smyslech? Jaké poznání zde má Kant na mysli? V Předmluvě k druhému vydání Kritiky čistého rozumu však čteme:

„Pokud se má v těchto vědách [tj. v matematice a fyzice] uplatnit rozum, musí v nich být něco poznáno a priori. Rozumové poznáni se pak může ke svému predmětu vztahovat dvojím způsobem: bud' že tento předmět a jeho pojem (který musí být dán odjinud) pouze určuje, nebo že ho také uskutečňuje. První způsob je teoretickým rozumovým poznáním, druhý rozumovým poznáním praktickým.“70

Veškeré poznání lze podle Kanta rozdělovat na poznání teoretické a praktické. Teoretické poznání spočívá v souzení o předmětu, v němž subsumujeme smyslový názor pod pojem, jenž předmětu odpovídá. Tím se z předmětu stává určený předmět. ${ }^{71}$ Praktické poznání rozumu uskutečňuje určitý účel (Zweck), a tím uskutečňuje svi̊j předmět. Člověk jako smyslová bytost poznává celou přírodu - i sám sebe - prostřednictvím smyslů, a je si sám pro sebe smyslovým předmětem neboli fenoménem. Kauzalita jeho libovůle (Willkür) jako fenoménu je podřízena bez výjimky zákonům přirody. Člověk je však prostřednictvím svého rozumu (či přesněji řečeno vůle [Wille] $)^{72}$ sám pro sebe i inteligibilním

69 I. Kant, Kritika čistého rozumu, str. 344 (A 546 n./B 574 n.; zvýraznil J. Ch.).

70 Tamt., str. 16 (B IX n.; zvýraznil J. Ch.).

71 Pro bližší výklad rozdílu mezi neurčeným předmětem (např. pojmem, „černý člověk“) a aktem jeho určování (např. soudem ,člověk je černý“) viz Kantův dopis Jakobu Sigismundu Beckovi z 3. 7. 1792. AA XI, str. 333.

72 Kant ve svém př́íručním exempláři první Kritiky ke slovům „To, že má rozum kauzalitu“ doplňuje: „tj. že je př́ičinou skutečnosti svých objektů. Tato kauzalita se nazývá vůle. V transcendentální filosofii ale od vůle abstrahujeme.“ I. Kant, Kritika čistého rozumu, str. 345 (AA XXIII, str. 50). 
předmětem neboli noumenem. V tomto ohledu člověk poznává sám sebe jako mravní bytost, která se podřizuje zákonu svobody neboli mravnímu zákonu. Poznání v praktickém ohledu však naše poznání ve spekulativním ohledu nijak nerozšiřuje. Kant $\mathrm{v}$ citované pasáži poukazuje pouze na to, že apercepce je propriem člověka, jímž se odlišuje od všech ostatních bytostí v prírodě. ${ }^{73}$

Kant vysvětluje spojení obou kauzalit u člověka v nauce o jeho dvojím charakteru. O pojmu „,charakter“ Kant v Kritice čistého rozumu píše: „Každá působící příčina musí mít určitý charakter, tj. zákon své kauzality, bez něhož by vủbec nebyla příčinou. " ${ }^{\text {"74 }}$ Pojem charakteru udává, jakým zákonem se kauzalita působící př́íiny řídí. Veškerý charakter lze rozdělit - s ohledem na oblast, které se týká - na charakter empirický a inteligibilní. Empirický charakter u subjektu smyslového světa udává, jak jsou jeho jednání určena jakožto jevy a jak spolu veskrze souvisejí podle stálých př́rodních zákonů. Co do svého empirického charakteru je smyslový subjekt jakožto jev podřízen zákonům prrírody a není ničím jiným než součástí smyslového světa. Subjektu smyslového světa však můžeme s ohledem na jeho mohutnost zvanou rozum přiznat též inteligibilní charakter. ${ }^{75}$ Jeho prostřednictvím je jednající subjekt sice příčinou jednání jakožto jevů, avšak sám není jevem. Co do svého inteligibilního charakteru není jednající subjekt podřízen podmínkám času, rrídí se pouze mravním zákonem. Pro vztah mezi oběma typy charakteru platí, že empirický charakter je jevem (Erscheinung) charakteru inteligibilního. ${ }^{76}$ O vztahu mezi oběma typy charakteru Kant píše:

„inteligibilní charakter by sice nikdy nemohl být bezprostředně poznán, protože vnímat dokážeme jen to, co se jeví, ale přece jen by

73 Tento motiv rozvíjí Kant na začátku své Anthropologie in pragmatischer Hinsicht, in: $A A$ VII, str. 127. K jeho výkladu viz J. Chotaš, Pojem „vědomí sebe sama" $v$ Antropologii v pragmatickém ohledu, str. $67 \mathrm{n}$.

74 I. Kant, Kritika čistého rozumu, str. 340 (A 539/B 567). Pojem charakteru v Kritice čistého rozumu je tedy odlišný od jeho běžného významu, v němž ,,charakter" chápeme jako povahový rys.

75 Ve spisu Náboženství v hranicích pouhého rozumu je nauka o obou charakterech člověka - charakteru empirickém (virtus phaenomenon) a inteligibilním (virtus noumenon) - dále rozvinuta (viz I. Kant, Náboženství v hranicích pouhého rozumu, přel. K. Šprunk, Praha 2013, str. 88 [AA VIII, str. 47]). Inteligibilní charakter si člověk dává inteligibilním skutkem (intelligibele Tat), zatímco empirický charakter skutkem smyslovým (sensible Tat) (viz tamt. str. 80 pozn.).

76 I. Kant, Kritika čistého rozumu, str. 341 n. (A 541/B 569). 
musel být v souladu s empirickým charakterem myšlen, stejně jako musíme jevům vůbec klást v myšlenkách za základ transcendentální předmět, třebaže o něm, co je sám o sobě, nic nevíme."77

Inteligibilní charakter tedy zůstává tak jako transcendentální předmět „skryt" za sférou jevů, ačkoli je v jistém ohledu jejich př́ičinou. Tento charakter nemůžeme nikdy poznat, protože smyslový názor je tím, prostřednictvím čeho nám může být předmět jedině dán, a můžeme jej pouze myslit. Přesto je však myšlenka inteligibilního charakteru nutná, protože jinak bychom jednajícímu subjektu nemohli žádná jednání přičítat (zurechnen). Myšlenka inteligibilního charakteru ale neznamená, že jednajícímu subjektu jako noumenu v pozitivním smyslu vskutku určitá jednání přičítat můžeme. O této otázce Kant píše:

„Vlastní moralita jednání (odměna a vina) - dokonce i moralita našeho vlastního chování - nám... zůstává zcela skryta. Otázky naši odpovédnosti se mohou týkat jen empirického charakteru. Kolik z toho je čistým účinkem svobody a kolik je třeba prripsat na vrub pouhé prírodě a nezaviněné vadě temperamentu, nebo jeho št’astné podobě (merito fortunae), nemůže nikdo zjistit, a proto ani zcela spravedlivě posoudit." ${ }^{\text {"78 }}$

Z citované pasáže vyplývá, že nám zůstává skryto, zda naše jednání jsou čistým účinkem svobody, či zda jsou determinována přírodními zákony. Nemůžeme proto nikdy s konečnou platností rozhodnout otázku, zda naše jednání bylo zapříčiněno kauzalitou ze svobody či kauzalitou podle zákonů prírody. Úvahu o dvojím zákonodárství v jednom a tomtéž člověku Kant shrnuje následovně:

„At’ se jedná o předmět pouhé smyslovosti (př́ijemné), anebo o předmět čistého rozumu (o dobré), rozum neustoupí tomu důvodu, který je dán empiricky, a nepodřídí se řádu věcí, jak se představují v oblasti jevu, nýbrž vytváŕí si s úplnou spontaneitou svůj vlastní řád podle idejí, jimž přizpůsobuje empirické podmínky, a podle nichž dokonce prohlašuje za nutná jednání, která se přesto nestala a možná ani nestanou. U všech nicméně předpokládá, že rozum by mohl mít vzhledem

77 Tamt.

78 Tamt., str. 347 (A 551/B 579 pozn.) 
k nim kauzalitu, nebot' bez toho by neočekával od svých idejí účinky ve zkušenosti."“79

Kantovu teorii sebepoznání člověka v teoretickém ohledu můžeme shrnout tak, že člověk se poznává pouze jako smyslová bytost, a to ve vztahu k jiným skutečným předmětům, které může v př́rodě kolem sebe vnímat. Kant netvrdí, že člověk je vždy schopen rozlišit, které z těchto předmětů jsou skutečné a které jsou smyšlené, ale pouze to, že „,vnitřní zkušenost vůbec je možná jen prostřednictvím vnější zkušenosti vůbec" ${ }^{80}$ Člověk se tedy v teoretickém ohledu poznává pouze tak, jako poznává ostatní jsoucna v př́rodě. Sebepoznání člověka není u Kanta archetypem poznání př́rody - jako je tomu např́iklad u Descarta -, ale spíše je tomu naopak: tak jak člověk poznává přírodu, poznává i sám sebe jako součást prírody.

Kantova teorie sebepoznání člověka v ohledu praktickém pak obsahuje podobný závěr. Jednající člověk jedná podle svého empirického charakteru, tj. podle toho, jak byl vychován a jaký má temperament, avšak jen neprímo může usuzovat na př́íčinu svého jednání. Přesto však Kant považuje za důležité, aby bylo možné jednání jednajícího člověka považovat za jeho vlastní, a proto rozvíjí myšlenku inteligibilního charakteru. Na tento charakter můžeme však podle Kanta usuzovat vždy pouze nepřímo, a to prostřednictvím empirického charakteru a jeho projevu v reálném světě. I v praktickém ohledu se tak člověk poznává pouze z účinků svého jednání ve smyslovém světě, a nikoli jak je sám o sobě, tj. jako noumenon v pozitivním smyslu. ${ }^{81}$

\section{ZUSAMMENFASSUNG}

Der Verfasser vertritt die These, dass laut Kant die Selbsterkenntnis des Menschen sehr begrenzt ist. In theoretischer Hinsicht erkennt sich der Mensch auf gleicher Art, wie er andere Gegenstände in der Natur erkennt. In praktischer Hinsicht erkennt sich der Mensch aus den Wirkungen, die seinen Handlungen in der Sinnenwelt folgen und von denen aus er lediglich indirekt auf ihre Ursache schließt. Zwar schreibt Kant dem

\footnotetext{
79 Tamt., str. 345 (A 548/B576).

80 Tamt., str. 185 (B 279).

81 Článek vznikl v rámci řešení výzkumného záměru Filosofického ústavu AV ČR, v. v. i.
} 
Menschen einen intelligiblen Charakter zu, dieser bleibt ihm aber unbekannt. In beiden Hinsichten erkennt sich der Mensch nur so, wie er sich erscheint, und nicht so, wie er an sich selbst ist.

\section{SUMMARY}

The author argues that for Kant man's self-knowledge is very limited. From the theoretical point of view, a man knows himself only in the same way as he knows other objects in nature. From the practical point of view a man knows himself according to the effects of his actions in the sensible world and, only indirectly, makes a conclusion about their cause. Kant ascribes to man an intelligible character, but this character remains hidden to him. From both points of views, therefore, a man knows himself only in the way as he appears to himself, and not as he is in himself. 